\title{
New Method for the Synthesis of 1-Methylimidazolium Trifluoroacetate and Its Application in Biginelli Reaction
}

\author{
Khan M. Hua, Thach N. Le ${ }^{*}$ \\ Department of Organic Chemistry, Faculty of Chemistry, University of Science, \\ Vietnam National University-Ho Chi Minh City, Ho Chi Minh City, Vietnam \\ Email: *1enthach@hom.vnn.vn
}

Received August 5, 2013; revised September 5, 2013; accepted September 12, 2013

Copyright (C) 2013 Khan M. Hua, Thach N. Le. This is an open access article distributed under the Creative Commons Attribution License, which permits unrestricted use, distribution, and reproduction in any medium, provided the original work is properly cited.

\begin{abstract}
A new method for the synthesis of 1-methylimidazolium trifluoroacetate ([Hmi]Tfa), a protic ionic liquid (PIL), under ultrasonic irradiation has been developed. In addition, the product [Hmi]Tfa was successfully employed as solvent and catalyst in Biginelli reaction to prepare 3,4-dihydropyrimidinones (DHPMs) in high yield under mild reaction conditions.
\end{abstract}

Keywords: Biginelli Reaction; Microwave Irradition; 1-Methylimidazolium Trifuoroacetate; Protic Ionic Liquid; Oxo-Monastrol; Ultrasonic Irradiation

\section{Introduction}

In recent years, ionic liquids (ILs) have attracted increasing interest and been successfully employed in variety of catalytic reactions as environmentally benign solvents and catalysts due to their relatively low viscosities, low vapor pressure, and high thermal and chemical stability, etc. $[1,2]$. Many organic processes can be significantly improved in ILs [1,3]. Particularly, protic ionic liquids (PILs) can play dual roles, solvent and catalyst, in some reactions. PILs are usually formed through the transfer of a proton from a Brönsted acid, $\mathrm{AH}$, to a Brönsted base, $\mathrm{B}$, to yield $\left[\mathrm{BH}^{+}\right]\left[\mathrm{A}^{-}\right]$species [4]:

$$
\mathrm{AH}+\mathrm{B} \rightarrow[\mathrm{BH}]^{+}\left[\mathrm{A}^{-}\right]
$$

3,4-Dihydropyrimidin-2-(1H)-ones (DHPMs) and their derivatives have recently attracted considerable interest because of their pharmacological properties and biological activities, such as potent calcium channel blockers, antihypertensive, antiviral, antiproliferative effect, standing against cancer cell lines, and potent HIV gp-120-CD4 inhibitors [5-8]. For example, DHPMs 1a, 1b were shown to have antiviral and anticancer activity. In addition, DHPMs monastrol and oxo-monastrol possess excellent anticancer activity [9-11].

DHPMs are usually prepared from 1,3-dicarbonyl, aldehyde and urea by Biginelli reaction. However, the clas-

\footnotetext{
"Corresponding author.
}

sical one-pot synthesis of DHPMs usually requires long reaction time while affording the product in moderate yield and low purity. Moreover, traditional catalysts are toxic and difficult to recycle leading to bad influence on environment. Recently, some alternative procedures have been reported involving Lewis acid catalyst such as $\left(\mathrm{Ce}\left(\mathrm{NO}_{3}\right)_{3} \cdot 6 \mathrm{H}_{2} \mathrm{O}\right.$ [12], $\mathrm{Cu}(\mathrm{OTf})_{2} / \mathrm{EtOH}$ [13], $\mathrm{InCl}_{3}$ [14], $\mathrm{NH}_{4} \mathrm{Cl}$ [15], $\mathrm{SrCl}_{2} \cdot 6 \mathrm{H}_{2} \mathrm{O}-\mathrm{HCl}$ [16]), or Brönsted acid (HCOOH [17]), montmorillonite KSF [18,19], zeolite (HY)/toluen [20]. Particularly, considerable attention has been paid to PILs such as [Hmi]Tfa and triethylbenzylammonium chloride (TEBA) [5].

Herein, we would like to report the synthesis of 1-methylimidazolium trifluoroacetate ([Hmi]Tfa) from trifluoroacetic acid and 1-methylimidazole under mild conditions using ultrasonic irradiation. [Hmi]Tfa was then applied as solvent and catalyst for Biginelli reaction to afford DHPMs in high yield and excellent purity. Additionally, the catalyst can be easily recycled without noticeable lost of reactivity.

\section{Experimental}

\subsection{Chemicals and Instruments}

Trifluoroacetic acid, ethyl acetoacetate, benzaldehyde, 3-hydroxybenzaldehyde,urea(Merck), 1-methylimidazole (Aldrich).

Products were characterized by melting point (Buchi 
B-545), IR (KBr, Shimadzu IR), and ${ }^{1} \mathrm{H},{ }^{13} \mathrm{C}$ NMR (Bruker, $500 \mathrm{MHz}$ ).

Ultrasonic bath (BRANSON 1510), focus microwave oven Discover (CEM).

\subsection{General Procedure for the Synthesis of [Hmi]Tfa}

1-Methylimidazole was placed in a two-necked flask, which was equipped with a magnetic stirrer and cooled in an ice bath $\left(0-5^{\circ} \mathrm{C}\right)$. A small amount of water was added and then trifluoroacetic acid (1 equiv.) was added slowly with stirring for $30 \mathrm{~min}$. After that the reaction was activated under ultrasonic irradiation at room temperature. Upon completion, water was removed on a rotary evaporator at $70^{\circ} \mathrm{C}$. The product was washed with diethyl ether to remove non-ionic residues and dried under vacuum.

\subsection{General Procedure for the Synthesis of DHPMs}

A mixture of aldehyde (2.5 mmol), 1,3-dicarbonyl compound $(2.5 \mathrm{mmol})$, urea $(3.75 \mathrm{mmol})$, and [Hmi]Tfa $(0.5$ g) was combined in a round-bottom flask. The mixture was stirred and activated by three methods: conventional heating, microwave, and ultrasonic irradiation. Upon completion, the reaction mixture was cooled in an icewater bath for $10 \mathrm{~min}$. Cold water $(10 \mathrm{~mL})$ was added and stirred for 5 - $10 \mathrm{~min}$. The crude product was filtered and washed with cold water $(5 \mathrm{~mL})$ and cold ethanol (15 $\mathrm{mL})$. The filtrate was extracted by ether to remove organic residues, water was removed on a rotary evaporator at $80^{\circ} \mathrm{C}$, then was washed with $\mathrm{CHCl}_{3}$ to remove urea. Thus, [Hmi]Tfa can be recovered.

1-Methylimidazolium trifluoroacetate: white solid; IR: $\left(\mathrm{KBr}, v_{\max } \mathrm{cm}^{-1}\right): 3152,2972,2872,1678,1589$, 1427, 1285, 1205, 1132. ${ }^{\mathbf{1}} \mathbf{H}$ NMR (DMSO-d 6 ) $\delta(\mathrm{ppm})$ : $3.885\left(\mathrm{~s}, 3 \mathrm{H}, \mathrm{CH}_{3}\right), 7.614\left(\mathrm{t}, 1 \mathrm{H}, \mathrm{H}_{5}, J=1.5 \mathrm{~Hz}\right), 7.659(\mathrm{t}$, $\left.1 \mathrm{H}, \mathrm{H}_{4}, J=1.5 \mathrm{~Hz}\right), 8.994\left(\mathrm{~s}, 1 \mathrm{H}, \mathrm{H}_{2}\right) .{ }^{13} \mathbf{C}$ NMR $\left(\mathrm{DMSO}_{6}\right) \delta(\mathrm{ppm}): 35.146,113.564,115.947,118.325$, $120.165,120.704,122.952$, 135.872, 158.197, 158.073, $158.321,158.573,158.822$.

5-Ethoxycarbonyl-6-methyl-4-phenyl-3,4-dihydropyri midin-2-one: white solid, m.p: $207-208^{\circ} \mathrm{C}$; IR ( $\mathrm{KBr}$, $v_{\max } \mathrm{cm}^{-1}$ ): 3245, 3117, 2979, 1726, 1646, 1465, 1388. ${ }^{1} \mathbf{H}$ NMR (DMSO-d $\left.{ }_{6}\right) \delta(\mathrm{ppm}): 1.094(\mathrm{t}, 3 \mathrm{H}, J=7.0 \mathrm{~Hz})$, 2.247 (s, 3H), 3.985 (q, 2H, $J=7.0 \mathrm{~Hz}), 5.146(\mathrm{~d}, 1 \mathrm{H}, J$ $=3.0 \mathrm{~Hz}), 7.222-7.247(\mathrm{~m}, 3 \mathrm{H}), 7.318(\mathrm{t}, 2 \mathrm{H}), 7.695(\mathrm{~s}$, 1H), $9.146(\mathrm{~s}, 1 \mathrm{H}) .{ }^{13} \mathrm{C}$ NMR (DMSO-d 6 ) $\delta(\mathrm{ppm}): 14.02$, $17.72,53.93,59.12,99.26,126.19,127.19,128.32$, 144.82, 148.27, 152.07, 165.30.

5-Ethoxycarbonyl-6-methyl-4-(3-hydroxyphenyl)-3,4dihydropyrimidin-2-one: yellow solid, m.p: $184-186^{\circ} \mathrm{C}$; IR $\left(\mathrm{KBr}, v_{\max } \mathrm{cm}^{-1}\right): 3518,3352,3244,3121,1726,1680$, 1641, 1600, 1458, 1224. ${ }^{1} \mathbf{H}$ NMR (DMSO-d 6 ) $\delta(\mathrm{ppm})$ : $1.122(\mathrm{t}, 3 \mathrm{H}, J=7.0 \mathrm{~Hz}), 2.250(\mathrm{~s}, 3 \mathrm{H}), 4.006(\mathrm{q}, 2 \mathrm{H}, J=$ $7.0 \mathrm{~Hz}), 5.085(\mathrm{~s}, 1 \mathrm{H}), 6.627-6.697(\mathrm{~m}, 3 \mathrm{H}), 7.101(\mathrm{t}$, $1 \mathrm{H}), 7.655(\mathrm{~s}, 1 \mathrm{H}), 9.120(\mathrm{~s}, 1 \mathrm{H}), 9.373(\mathrm{~s}, 1 \mathrm{H}) .{ }^{13} \mathrm{C}$ NMR (DMSO-d 6 ) $\delta(\mathrm{ppm}): 14.030,17.693,53.836$, 59.169, 99.520, 113.099, 114.169, 116.881, 129.225, $146.183,147.936,152.215,157.284,164.399$.

\section{Results and Discussion}

\subsection{Synthesis of [Hmi]Tfa (Scheme 1)}

Optimal conditions for the synthesis of ionic liquid [Hmi]Tfa: the molar ratio of trifluoroacetic acid and 1methylimidazole was chosen 1:1. The results are shown in Table 1.

Because the reaction between 1-methylimidazole and trifluoroacetic acid is exothermic, it was performed at ambient temperature $\left(30^{\circ} \mathrm{C}\right)$. The control reaction without sonication resulted in slightly lower yield while required longer time. The benefit of ultrasonic irradiation has been shown by higher yield of product. The most important effect of ultrasonic is by passing its waves through a liquid medium in the generation of energy. The driving energy is provided by cavitation, the formation and collapse of bubble, which liberates considerable energy in very short time.

\subsection{Synthesis of DHPMs}

We report here the application of different activation methods on Biginelli condensation to produce 3,4-dihydropyrimidinones using [Hmi]Tfa catalyst under solventfree conditions (Scheme 2).

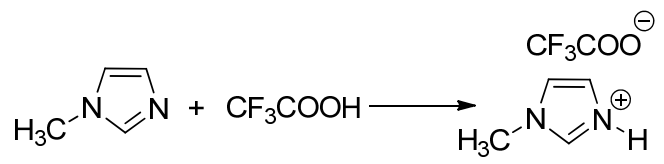
Scheme 1. Synthesis of [Him]Tfa.<smiles>CCOC(=O)CC(C)=O</smiles>

Scheme 2. The Biginelli synthesis of DHPMs.

Table 1. Synthesis of [Hmi]Tfa by ultrasonic irradiation.

\begin{tabular}{ccccc}
\hline Entry & $\begin{array}{c}\text { Ratio } \\
\text { acid:base }\end{array}$ & $\begin{array}{c}\text { Temperature } \\
\left({ }^{\circ} \mathrm{C}\right)\end{array}$ & $\begin{array}{c}\text { Time } \\
(\min )\end{array}$ & $\begin{array}{c}\text { Yield } \\
(\%)^{\mathrm{a}}\end{array}$ \\
\hline 1 & $1: 1$ & 30 & 15 & 88 \\
2 & $1: 1$ & 30 & 30 & 92 \\
3 & $1: 1$ & 30 & 45 & 94 \\
4 & $1: 1$ & 30 & 60 & 95 \\
$5^{\mathrm{b}}$ & $1: 1$ & 30 & 120 & 92 \\
\hline
\end{tabular}

${ }^{\mathrm{a}}$ Isolated yield. ${ }^{\mathrm{b}}$ Without ultrasonic irradiation. 
The one-pot synthesis of DHPMs under different conditions involving the condensation of aromatic aldehydes, 1,3-dicarbonyl, urea has been extensively studied. However, many of these methods employ expensive catalysts which are difficult to recycle and reuse, long reaction time, strongly acidic conditions, and difficult to handle especially on large scale. Therefore, the discovery of an inexpensive catalyst for the preparation of DHPMs under neutral and mild conditions is of prime importance.

Due to the increasing environmental and economical concerns in recent years, it is now essential for chemists to search for environmentally benign catalytic processes. In this report, [Hmi]Tfa was employed in Biginelli reaction under mild and solvent-free conditions. In addition, we hope that [Hmi]Tfa will be applicable as a ecofriendly solvent-catalyst for other organic reactions.

The scope of aromatic aldehydes are summarized in Table 2. In most cases, products were obtained in good yields under mild conditions. Microwave irradiation offered the best yield in comparison with other methods. To our best knowledge, this is the first high yielding Biginelli systhesis of DHPMs [18,20].

Consequently, the possibility to recycle catalyst was examined. As shown in Table 3, [Hmi]Tfa could be reused without significant loss of activity.

Table 2. Scope of aromatic aldehydes.

\begin{tabular}{|c|c|c|c|c|c|}
\hline Entry & Ar- & Catalyst & $\begin{array}{c}\text { Temperature } \\
\left({ }^{\circ} \mathrm{C}\right)\end{array}$ & Time & $\begin{array}{l}\text { Yield } \\
(\%)^{*}\end{array}$ \\
\hline $1^{\mathrm{a}}$ & $\mathrm{C}_{6} \mathrm{H}_{5^{-}}$ & [Hmi]Tfa, $0.5 \mathrm{~g}$ & 90 & $60 \mathrm{~min}$ & $85^{\mathrm{d}}$ \\
\hline $2^{\mathrm{a}}$ & $\mathrm{C}_{6} \mathrm{H}_{5^{-}}$ & $\mathrm{KSF}, 45 \mathrm{~mol} \%$ & 130 & $48 \mathrm{~h}$ & 82 [18] \\
\hline $3^{\mathrm{a}}$ & $\mathrm{C}_{6} \mathrm{H}_{5^{-}}$ & $\mathrm{HY} /$ Toluen, $0.5 \mathrm{~g}$ & 100 & $12 \mathrm{~h}$ & 80 [20] \\
\hline $4^{\mathrm{a}}$ & $3-\mathrm{HO}-\mathrm{C}_{6} \mathrm{H}_{5}-$ & [Hmi]Tfa, $0.5 \mathrm{~g}$ & 90 & $60 \mathrm{~min}$ & $88^{\mathrm{d}}$ \\
\hline $5^{\mathrm{b}}$ & $\mathrm{C}_{6} \mathrm{H}_{5-}^{-}$ & [Hmi]Tfa, $0.5 \mathrm{~g}$ & 106 & $20 \mathrm{~min}$ & $83^{\mathrm{d}}$ \\
\hline $6^{\mathrm{b}}$ & $\mathrm{C}_{6} \mathrm{H}_{5^{-}}$ & $\begin{array}{c}\mathrm{Cu}(\mathrm{OTf})_{2} \\
2 \mathrm{~mol} \% / \mathrm{EtOH}\end{array}$ & 100 & $1 \mathrm{~h}$ & 95 [13] \\
\hline $7^{\mathrm{b}}$ & $\mathrm{C}_{6} \mathrm{H}_{5^{-}}$ & $\mathrm{HCOOH}, 25$ mol\% & $90(120 \mathrm{~W})$ & $4 \min$ & 92 [17] \\
\hline $8^{b}$ & $3-\mathrm{HO}-\mathrm{C}_{6} \mathrm{H}_{5^{-}}$ & [Hmi]Tfa, $0.5 \mathrm{~g}$ & 110 & $20 \min$ & $85^{\mathrm{d}}$ \\
\hline $9^{c}$ & $\mathrm{C}_{6} \mathrm{H}_{5^{-}}$ & [Hmi]Tfa, $0.5 \mathrm{~g}$ & 30 & $120 \mathrm{~min}$ & $21^{\mathrm{d}}$ \\
\hline $10^{\mathrm{c}}$ & $3-\mathrm{HO}-\mathrm{C}_{6} \mathrm{H}_{5}-$ & {$[\mathrm{Hmi}] \mathrm{Tfa}, 0.5 \mathrm{~g}$} & 30 & $120 \mathrm{~min}$ & $22^{\mathrm{d}}$ \\
\hline
\end{tabular}

${ }^{\mathrm{a}}$ The reaction was heated with stirring. ${ }^{\mathrm{b}}$ Microwave irradiation. ${ }^{\mathrm{c}}$ Ultrasonic irradiation at room temperature. ${ }^{\mathrm{d}}$ Reaction conditions: aldehyde $(2.5 \mathrm{mmol})$, ethyl acetoacetate $(2.5 \mathrm{mmol})$, urea $(3.75 \mathrm{mmol})$ and [Hmi]Tfa $(0.5 \mathrm{~g})$. *Isolated yield.

Table 3. Recycling of [Hmi]Tfa in Biginelli reaction ${ }^{\mathrm{a}}$.

\begin{tabular}{cc}
\hline Cycle & Yield (\%) \\
\hline 1 & 85 \\
2 & 83
\end{tabular}

${ }^{\mathrm{a}}$ Benzaldehyde $(2.5 \mathrm{mmol})$, ethyl acetoacetate $(2.5 \mathrm{mmol})$, urea $(3.75 \mathrm{mmol})$, $90^{\circ} \mathrm{C}, 60 \mathrm{~min}$, [Hmi]Tfa $0.5 \mathrm{~g}$.

\section{Conclusion}

The first application of ultrasonic irradiation on the synthesis of [Hmi]Tfa has been studied. [Hmi]Tfa could be obtained in high yield and short reaction time. [Hmi]Tfa has been successfully applied as solvent and catalyst for Biginelli reaction. The reaction is easy to be handled enabling large scale applications of this eco-friendly process. [Hmi]Tfa can be considered as "green" solvent and catalyst in organic synthesis because it can be easily recycled and reused.

\section{Acknowledgements}

We are grateful to Nafosted (National Foundation for Science and Technology Development, Vietnam) for financial support through contract No. 104.01-2010.34.

\section{REFERENCES}

[1] H. Olivier-Bourbigou, L. Magna and D. Morvan, "Ionic Liquids and Catalysis: Recent Progess from Knowledge to Applications," Applied Catalysis A: General, Vol. 373, No. 1-2, 2009, pp. 1-56. http://dx.doi.org/10.1016/j.apcata.2009.10.008

[2] S. Zhang, N. Sun, X. He, X. Lu and X. Zhang, "Physical Properties of Ionic Liquids: Database and Evaluation," Journal of Physical and Chemical Reference Data, Vol. 35, No. 4, 2006, pp. 1475-1517. http://dx.doi.org/10.1063/1.2204959

[3] N. Jain, A. Kumar, S. Chauhan and S. M. S. Chauhan, "Chemical and Biochemical Transformations in Ionic Liquids," Tetrahedron, Vol. 61, No. 5, 2004, pp. 1015-1560. http://dx.doi.org/10.1016/j.tet.2004.10.070

[4] L. G. Tamar and J. D. Calum, "Protic Ionic liquids: Properties and Applications," Chemical Reviews, Vol. 108, No. 1, 2008, pp. 206-237. http://dx.doi.org/10.1021/cr068040u

[5] D. S. Bose, M. Sudharshan and W. C. Sanjay, "New Protocol for Biginelli-A Practical Synthesic of Monastrol," Arkivoc, 3, 2005, pp. 228-236. http://www.arkat-usa.org/get-file/19242/

[6] M. A. A. Abdulkarim and G. M. Nareruddin, "An Ultrasonic Assisted Mutilcomponent Reaction for Synthesic of 3,4-Dihydropyrimidin-2(1H)-ones under Solvent-Free Condition," Journal of Chemical and Pharmaceutical Research, Vol. 2, No. 3, 2010, pp. 536-543.

http://jocpr.com/vol2-iss3-2010/JOCPR-2010-2-3-536-54 3.pdf

[7] Y.-X. Li and W. L. Bao, "Microwave-Assisted Solventless Biginelli Reaction Catalyzed by Montmorillonite Clay-SmCl $\mathrm{Sm}_{3} \cdot 6 \mathrm{H}_{2} \mathrm{O}$ System," Chinese Chemical Letters, Vol. 14, No. 10, 2003, pp. 993-995. http://d.wanfangdata.com.cn/periodical_zghxkb20031000 2.aspx

[8] S. F. Fabio and C. O. Kappe, "The Biginelli Dihydropyrimidone Synthesis Using Polyphosphate Ester as a Mild and Efficient Cyclocondensation/Dehydration Re- 
agent," Arkivoc, Vol. 2001, No. 2, 2001, pp. 122-134. http://dx.doi.org/10.3998/ark.5550190.0002.214

[9] D. Russowsky, F. S. C. Romulo, A. A. S. Sergio, G. M. D. Marcelo, A. Fatima, A. P. Ronaldo, K. K. Luciana, A. A. Marcia and J. E. Carvalho, "Synthesis and Differential Antiproliferative Activity of Biginelli Reaction Compounds againts Cencer Cell Lines: Monastrol, OxoMonastrol and Oxygenated Analogues," Bioorganic Chemistry, Vol. 34, No. 4, 2006, pp. 173-182. http://dx.doi.org/10.1016/j.bioorg.2006.04.003

[10] F. S. C. Romulo, A. Bernardi, O. B. A. Maria, D. Russowsky and V. L. Eifler-Lima, "Synthesis of Dihydropyrimidin-2-one/thione Library and Cytotoxic Activity Against the Human U138-MG and Rat C6 Glioma Cell Lines," Journal of the Brazilian Chemical Society, Vol. 22, No. 7, 2011, pp. 1379-1388. http://dx.doi.org/10.1590/S0103-50532011000700025

[11] A. Mobinikhaledi and M. Kalhor, "Synthesis and Biological Activity of Some Oxo-and Thioxopyridines," International Journal of Drug Development and Research, Vol. 2, No. 1, 2010, pp. 68-272.

http://ijddr.in/old/ijddr\%20\%20vol.\%202\%20issue \%202/ vol2.\%20issue2,\%20no.\%205.pdf

[12] M. Adib, K. Ghanbary, M. Mostofi and M. R. Ganjali, "Efficient $\mathrm{Ce}\left(\mathrm{NO}_{3}\right)_{3} \cdot 6 \mathrm{H}_{2} \mathrm{O}$-Catalyzed Solvent-Free Synthesis for 3,4-Dihydropyrimidin-2(1H)-ones," Molecules, Vol. 11, No. 8, 2006, pp. 649-654. http://dx.doi.org/10.3390/11080649

[13] K. K. Pasunooti, H. Chai, C. N. Jensen, B. K. Gorityala, S. Wang and X. W. Liu, "A Microwave-Assisted, CopperCatalyzed Three-Component Synthesis of Dihydropyrimidinones under Mild Conditions," Tetrahedron Letters, Vol. 52, No. 1, 2011, pp. 80-84. http://dx.doi.org/10.1016/j.tetlet.2010.10.150

[14] C. R. Brindadan, A. Hajra and U. Jana, "Indium(III) Chloride-Catalyzed One-Pot Synthesis of Dihydropyrimidinones by a Three-Component Coupling of 1,3-Dicarbonyl Compounds, Aldehides, and Ure: An Improved Procedure or the Biginelli Reaction," The Journal of Organic Chemistry, Vol. 65, No. 19, 2000, pp. 6270-6272. http://dx.doi.org/10.1021/jo000711f

[15] 15. A. Shaabani, A. Bazgir and F. Teimouri, "Ammonium Chloride-Catalyzed One-Pot Synthesis of 3,4-Dihydropyrimidin-2-(1H)-ones under Solvent-Free Conditions," Tetrahedron Letters, Vol. 44, No. 4, 2003, pp. 857-859. http://dx.doi.org/10.1016/S0040-4039(02)02612-6

[16] M. Nasr-Esfahani and A. R. Khosropour, "An Efficient and Clean One-Pot Synthesis of 3,4-Dihydropyrimidine2-(1H)-ones Catalyzed by $\mathrm{SrCl}_{2} \cdot 6 \mathrm{H}_{2} \mathrm{O}-\mathrm{HCl}$ in Solvent or Solvent-Free Conditions," Bulletin of the Korean Chemical Society, Vol. 26, No. 9, 2005, pp. 1331-1332.

http://journal.kcsnet.or.kr/main/j_search/j_download.htm ?code $=$ B050902

http://dx.doi.org/10.5012/bkcs.2005.26.9.1331

[17] C. Jiang and Q. D. You, "An Efficient and Solvent-Free One-Pot Synthesis of Dihydropyrimidionnes under Microwave Irradiation," Chinese Chemical Letters, Vol. 18, No. 6, 2007, pp. 647-650.

http://dx.doi.org/10.1016/j.cclet.2007.04.002

[18] 18. F. Bigi, S. Carloni, B. Frullanti, R. Maggi and G. Sartori, "A Revision of the Biginelli Reaction under Solid Acid Catalysis. Solvent-Free Synthesis of Dihydropyrimidines over Montmorillonite KSF," Tetrahedron Letters, Vol. 40, No. 19, 1999, pp. 3465-3468. http://dx.doi.org/10.1016/S0040-4039(99)00424-4

[19] H. Lin, J. Ding, X. Chen and Z. Zhang, "An Efficient Synthesis of 3-Alkoxycarbonyl-4-aryl-3,4-dihydro-pyrimidin-2(1H)-ones Catalyzed by KSF Montmorillonite," Molecules, Vol. 5, No. 12, 2000, pp. 1240-1243. http://www.mdpi.org/molecules/papers/51201240.pdf http://dx.doi.org/10.3390/51201240

[20] V. R. Rani, N. Srinivas, M. R. Kishan, S. J. Kulkarni and K. V. Raghavan, "Zeolite-Catalyzed Cyclocondensation Reaction for the Selective Synthesis of 3,4-Dihydropyrimidin-2(1H)-ones," Green Chemistry, Vol. 3, No. 6, 2001, pp. 305-306. http://dx.doi.org/10.1039/b107612b 